\title{
The rhythms of the Rock
}

I $\mathrm{n}$ an era in which genomics is being assailed in some quarters as having failed to yield its promised transformation of clinical practice, thousands of Canadians living on the Rock would beg to differ.

With very little fanfare, their little corner of the country has become a staging ground on which genomics is actually reconfiguring the discipline of cardiology, albeit while raising several knotty ethical and legal issues.

It also has effected substantive changes in the diagnosis and treatment of Newfoundlanders, particularly young men, afflicted with a rare heart arrhythmia euphemistically referred to as "The Newfoundland Curse."

The disorder is characterized by sudden death among members of select families. Until recently, it was a clinical mystery as to who was at risk. "The only thing we could do with them was a constant clinical" screen- ing, says Dr. Christina Templeton, a pediatric cardiologist at the Janeway Children's Health Centre in St. John's, Newfoundland and Labrador.

But in 1997 researchers from Baylor University in Waco, Texas, under the direction of Dr. Robert Roberts, now head of Ottawa Heart Institute in Ontario, found the general location of the gene associated with a Newfoundland-specific version of arrhythmogenic right ventricular cardiomyopathy (ARVC).

In 2008, the precise gene that causes the curse was identified by a team headed by Terry-Lynn Young, a molecular geneticist at Memorial University in St. John's, Newfoundland and Labrador. It is now among more than half dozen ARVC genes that are routinely tested for. It is highly penetrant, with some $50 \%$ of male carriers dying by the age of 40 , and $80 \%$ by age 50. An estimated 1 in 5000 people have ARVC (Z Kardiol 1999; 550-54). Among isolated, outport populations of Newfoundlanders, where kin marriage has occurred, the incidence rate drops to 1 in 500, according to Kathy Hodgkinson, an assistant professor of clinical epidemiology at Memorial University in St. John's.

Hodgkinson says that a reading of family Bibles suggests the Newfoundland variant manifested itself in the 18th century among the descendants of an Anglican immigrant from Great Britain, and has since been tracked through 10 generations and 22 families (www.ichg2011.org/cgi-bin/showdetail .pl?absno=11096).

As a consequence of all of those developments, it is now recommended that either an implantable or external defibrillator be provided to male carriers in their late teens, and female carriers in their late 20s, even if they have no clinical symptoms.

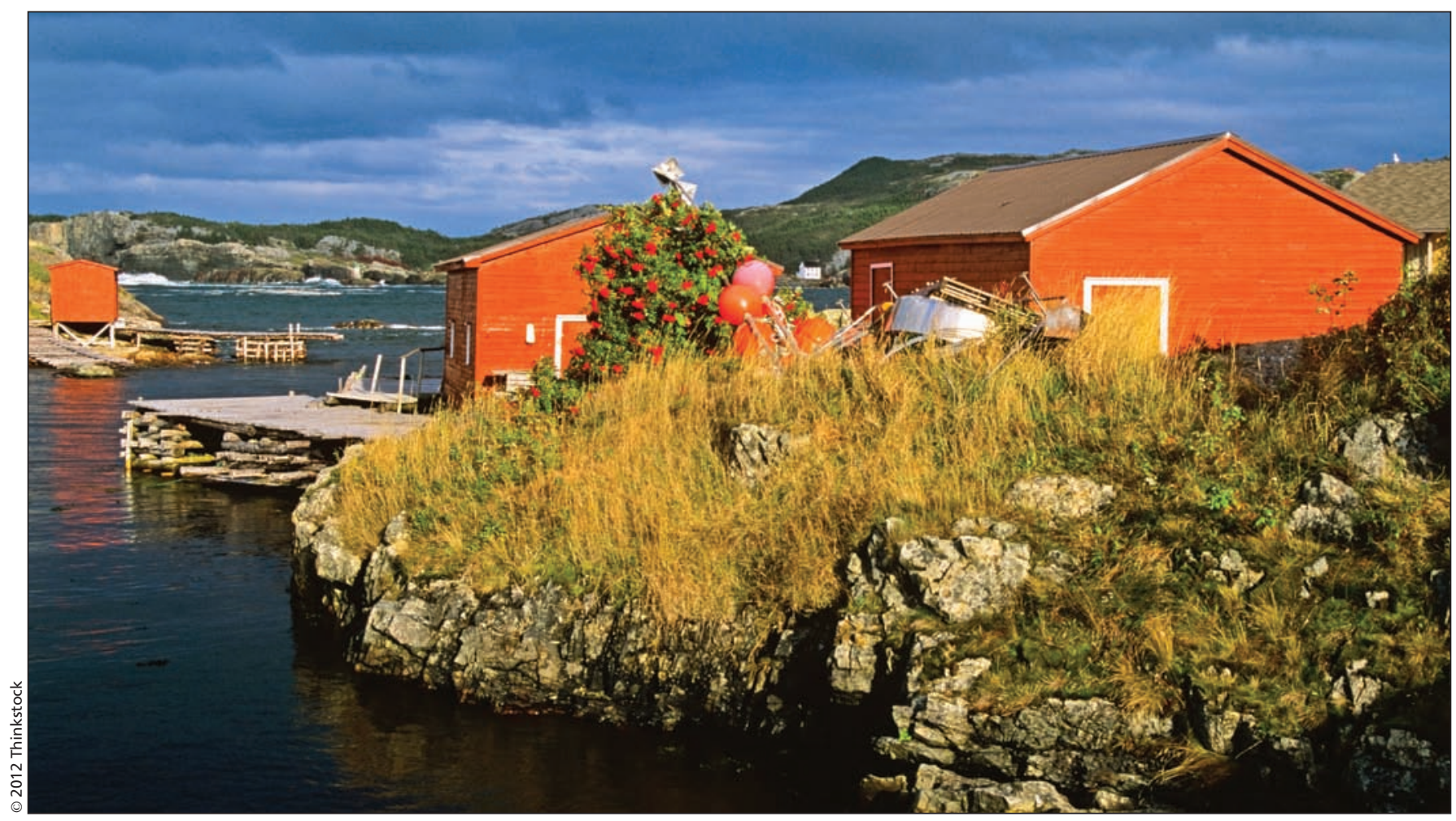

Many residents of Newfoundland and Labrador, particularly young men, have been afflicted with a rare heart arrhythmia euphemistically referred to as "The Newfoundland Curse." 
That has resulted in 10 times fewer the number of male deaths, when compared with carriers without defibrillators. "A less dramatic but similar decrease in death rates have been noted in women," Hodgkinson says.

Templeton says an ARVC test has "revolutionized my practice in ten years. That is in my practice life time."

For people like Elizabeth Webster, it's meant life. After suffering a stroke in 2010, she was being examined by cardiologist Dr. Sean Connors at the St. John's General Hospital and over the course of their conversation, "he recognized my grandmother's maiden name as one of the families who might have the gene." It led to implantation of a defibrillator in both Webster and her son.

Darryl Pullman, a bioethicist at Memorial, says the developments have made Newfoundland ARVC, rather than Huntington Disease, the new exemplar for genetic testing. "Huntington's set the bar initially because it was the first condition where we had a definitive test," he notes. "But it was "now you have it, and we know you are going to die of it, but there is nothing we can do about it'. But ARVC is kind of at the other extreme; we have a definitive test now and we have a treatment."

With success have come ethical issues. Parents are now demanding that children be tested as early as age eight, though there is no clinical justification for doing so before the late teens. Templeton and others are concerned parents will curb the activity levels of children, which has its own negative health consequences.

Others have urged province-wide testing for ARVC. But that may ultimately prove very costly if the number of people who are identified as being at risk of rapid cardiac death increases as a result of an ongoing \$5-million collaborative study aimed at ascertaining whether there are additional genes and mutations that put people at risk, Pullman notes. "What if we discover a certain number of people who are at risk, do we have the clinical resources to deal with it? Do we have the resources available to say, you are now at risk of sudden cardiac death, you need to have a defibrillator put in?"

As thorny have been such cases as one in which a young man wanted a defibrillator removed because he didn't like the look of it. His mother objected and went to court (B.D. v Eric W. Stone and Eastern Regional Health Integrated Authority, 2006NLTD161) to prevent it. The Newfoundland Supreme Court upheld the man's right to make his own choice. Months later, an emergency team saved him after a heart attack and the defibrillator has since been reinstalled.

That begs the question as to whether the province should pay for future removal, or re-insertion, of defibrillators because of such a cosmetic consideration.

Either way, Newfoundland ARVC has rattled even genomics skeptics like Tim Caulfield, research director of the Health Law Institute at the University of Alberta, who has called for deflation of the "genomic bubble" (Science 2011;331:861-62). "It is almost like a pocket of universe where the predicted applications of genomic technology are playing out," says a bemused Caulfield. "I hate this expression but I will use it: Is it the exception that proves the rule?" - Stephen Strauss, Toronto, Ont.

CMAJ 2012. DOI:10.1503/cmaj.109-4102

First of a three part series:

\section{Part 2: The heartbeat of a First} Nation

(www.cmaj.ca/lookup/doi/10.1503 /cmaj.109-4103).

Part 3: The all-clear signal for rare heart arrhythmias

(www.cmaj.ca/lookup/doi/10.1503 /cmaj.109-4104).

Stephen Strauss' research was made possible in part by a $\$ 20000$ Canadian Institutes of Health Research Journalism Award. 